FAMÍLIA E COMUNIDADE

EM FOCO

\title{
REVISITANDO A IV JORNADA PAULISTA DE PSICOLOGIA EM REPRODUÇÃO ASSISTIDA
}

NEUSA IVETE GEROMEL BORSOI

Pedagoga, São Caetano do o participar da Jornada realizada em 02 de dezembro de 2017, na cidade de São Paulo, pela Sociedade Paulista de Medicina Reprodutiva, fui alimentada por saberes que me instigaram a olhar o quanto a fecundidade humana transcende o biológico ao atender a uma rede de crenças e desejos pessoais e socioculturais.

Desde os primórdios da história, os aspectos relacionados à infertilidade e à reprodução foram preocupações do ser humano. Numa passagem bíblica, Sara, mulher de Abraão, ao perceber que não podia conceber, aconselha o marido a ter um filho com uma de suas escravas.

Ao longo do tempo, muitas pesquisas científicas sobre a infertilidade aconteceram, mas só em julho de 1978, fruto da técnica de fertilização in vitro, nasce Joy Brown, num hospital da Inglaterra. Atualmente estudos apontam que o projeto parental é universal e que apenas uma parcela de $5 \%$ opta por não ter filhos.

A tendência da mulher moderna em postergar a maternidade em detrimento da realização profissional pode ser o principal fator de risco para a infertilidade. Há, ainda, porém, outros importantes fatores de risco a serem considerados: uma vida sexual iniciada precocemente e sem maturidade, os hábitos de vida sedentários, a obesidade, o tabagismo, o consumo excessivo de álcool e o uso de drogas ilícitas. Na mulher os problemas relacionados com disfunção ovariana exercem papel preponderante na gênese da infertilidade.

Vale observar que o congelamento de oócitos (células germinativas femininas) ainda é técnica considerada de caráter experimental.

Como Terapeuta de Casal e Família, tenho me deparado com novas construções familiares fruto do pluralismo das relações afetivas: casais advindos de separações em novos casamentos, casais constituídos por indivíduos de mesmo sexo/gênero e por indivíduos que isoladamente desejam assumir a monoparentalidade. A citação abaixo reconhece que essas novas construções familiares são fatos consumados.

A evolução do conhecimento científico - somado ao fenômeno da globalização, ao declínio do patriarcalismo e à redivisão sexual do trabalho - fez uma grande transformação da família, especialmente a partir da segunda metade do século passado. Como será a família desse novo século (...)? Não é necessário mais sexo para reprodução, e o casamento legítimo não é mais a única maneira de se legitimar as relações sexuais (...). Afora a nostalgia de que a família na qual cada um de nós foi criado é a melhor, sua travessia para o novo milênio se faz em um barco que está transportando valores totalmente diferentes, como é natural dos fenômenos de virada de século. A travessia nos deixa atônitos, mas traz consigo um valor que é uma conquista, ou seja, a família não é mais essencialmente um núcleo econômico e de reprodução 
em que sempre esteve instalada a suposta superioridade masculina. Nessa travessia, carregamos a "boa nova" de que ela passou a ser muito mais o espaço para o desenvolvimento do companheirismo, do amor e, acima de tudo, embora sempre tenha sido assim, e será, o núcleo formador da pessoa e fundante do sujeito. (Pereira 2003, apud Abrahão, 2003 in Melamed, Seger, Borges, 2009)

Na IV Jornada Paulista de Psicologia em Reprodução Assistida os temas apresentados, sem a pretensão de esgotar o assunto, foram abrangentes e abordaram um conjunto de técnicas com seus prós e contras, que visam à reprodução humana e à importância do trabalho psíquico com as pessoas que procuram a RA. Dentre os temas apresentados, em quatro mesas denominadas: Formas Abrangentes do Trabalho do Psicólogo em RA, Novas Formas de Parentalidade, Utilização de Material de Terceiros e Impasses em RA, tenho a oportunidade de deixar registrado, em Família e Comunidade em Foco, falas que me afetaram e enriqueceram minha escuta terapêutica:

- Preservação da fertilidade em tratamentos de câncer (Ana Rosa Detilio)

O câncer e a infertilidade mobilizam emoções e necessitam de ajustes que tangem questões primitivas, sociais, éticas e religiosas. As necessidades individuais da mãe devem ser respeitadas e consideradas na vida futura dela, com a preservação da fertilidade através da criopreservação de espermatozoides, óvulos e embriões.

- Aspectos emocionais da gestação pós-tratamento RA (Julieta Quayle)

Pesquisas apontam que após o $4^{\circ}$ mês de gestação e no período pós-parto o índice de depressão é mais incidente com mulheres de idade mais avançada. Um quadro depressivo também pode ser diagnosticado entre 2 a 12 meses após o nascimento da criança, especialmente em casos de gêmeos e trigêmeos, considerando a demanda, não fácil, que nessa idade as crianças solicitam.

- O papel da psicoeducação em RA (Liliana Seger)

Todos os pacientes precisam de terapia. Quando existe um trabalho multidisciplinar, uma equipe que aponta a necessidade de um suporte psicológico, os pacientes são encorajados para falar de suas emoções e sentimentos quanto à infertilidade e de suas preocupações com o enfrentamento de RA. Sentir-se-ão acolhidos desde o momento do diagnóstico das possíveis causas da infertilidade, por todo o processo de RA e, principalmente, nos momentos críticos do tratamento.

- O casal homoafetivo no contexto de RA - vivências emocionais (Helena Prado)

Hoje não podemos nos distanciar dos casais homoafetivos e do desejo deles de terem filhos. Quando decidem ter filhos, observar: para quem o filho? Por que o filho? Isso envolve terceiros? (um óvulo, um sêmen, um empréstimo de útero).

O psicólogo precisa se livrar de seus preconceitos e aceitar esse casal como casal, considerando tratar-se de uma configuração familiar que traz questões singulares, sem perder de vista que o amor desse casal é o bem-estar dos filhos.

- Coparentalidade - os novos arranjos para se ter um filho (Luciana Leis) Como ponto de reflexão: se a formação da subjetividade necessita, para se constituir, de alguém que represente a lei e na coparentalidade, "o casal" assume, 